\title{
Geregtigheid, huisorde en die jubilee in
}

Matteus

\author{
G J Volschenk (Pongola) ${ }^{1}$ \\ Navorsingsassosiaat: Departement Nuwe-Testamentiese Wetenskap \\ Universiteit van Pretoria
}

\begin{abstract}
Justification, house-order and jubilee in Matthew

The aim of this article is to describe the relationship between justification, house-order and jubilee in Matthew. There is both a horizontal and a vertical dimension to justification, as well as it having multiple nuanced meaning possibilities. By means of a triangular model the article describes the interdependent and interrelational nature of the relationship between justification, house-order and jubilee. The triangular model is an interpretation framework to avoid the one dimensional and simplistic understanding of justification and jubilee. The article concludes with a broad understanding of the jubilee which confirms its multi-dimensional nature and God's new beginning with humanity in Jesus Christ.
\end{abstract}

\section{INLEIDING}

Die doel van die onderhawige studie is om die verband tussen geregtigheid, huisorde en jubilee aan te toon. Matteus verstaan geregtigheid as die vervulling van die wet en profete. Jesus is die "beeld" van die Goddelike tora, wat God se "ekonomie" is, dit wil sê God se manier om geregtigheid te versprei. Geregtigheid is verder die basis van die wet en ordening van die geloofsgemeenskap as huishouding. In hierdie artikel word aangetoon dat geregtigheid 'n horisontale en vertikale dimensie het en dat geregtigheid genuanseerde gebruiksmoontlikhede het. 'n "Driehoekmodel" word voorgestel om die interafhanklike en

\footnotetext{
${ }^{1}$ Dr Gert J Volschenk (MDiv, DD) is as navorsingsassosiaat betrokke by prof dr Andries G van Aarde se navorsingsprojek "Bybelse Teologie en Hermeneutiek", Departement NuweTestamentiese Wetenskap, Fakulteit Teologie, Universiteit van Pretoria. Hierdie artikel is 'n verwerking van 'n deel van dr Volschenk se DD-proefskrif, "Eksegeties-metodologiese vooronderstellings van die ondersoek na die ekonomie in die leefwêreld van Matteus: Toegepas op land, grondbesit en die jubilee", Universiteit van Pretoria (2001).
} 
interrelasionele aard van die verhouding tussen geregtigheid, huisorde en jubilee aan te toon. Die driehoekmodel dien as interpretasieraamwerk wat 'n eendimensionele en simplistiese verstaan van geregtigheid en jubilee uitskakel. Die ondersoek toon 'n verruimde verstaan van jubilee wat multi-dimensioneel van aard is en op God se totale nuwe begin met die mens in Jesus Christus dui.

\section{GEREGTIGHEID IN MATTEUS SE HUISKERKE}

Matteus is die enigste evangelis (behalwe die gebruik in Luk 1:75) wat die woord geregtigheid of dikaiosune gebruik (vgl Engelbrecht 1985:158). Omdat al die gebruike oënskynlik redaksioneel is, is die gebruik van die terme belangrik vir die verstaan van Matteus. ' $n$ Verstaan van die woord se gemeentelike konteks is belangrik. Matteus se gemeenskap het 'n sterk groep ${ }^{2}$ eienskap (Leland-White 1986:63). Die gemeenskap word verstaan as 'n "huis van geregtigheid" in 'n onregverdige wêreld (Matt 5:45; 13:47-50; 23:28; 25:31-46). Jesus se onderrig is die norme wat Matteus se gemeenskap as regverdiges onderskei van die onregverdiges. Die norme trek skerp grense en onderskei die gemeenskap as 'n sterk groep. Volgens Leland-White (1986:63; vgl Crosby 1988:179) is die Matteusgemeenskap 'n lae graad gemeenskap. Lae graad beteken 'n lae graad van bande tussen mense se ervaring en hulle gemeenskap se patroon van persepsie, evaluasie, horison of paradigma. Die lae graad van Matteus se huiskerke is sigbaar in hulle egalitêre benadering tot status, rolle en gedrag. Crosby (1988:179) stel tereg dat eer en skande die sentrale morele waarde van die gemeenskap se verhoudings is:

\footnotetext{
${ }^{2}$ Mary Douglas (1966) gebruik kultureel-antropologiese modelle om die samestelling van die Christelike gemeenskap te beskryf. Die gemeenskap kan beskryf word as high/low grid en strong/weak group (vgl Crosby 1988:111; Leland White 1986). Met die begrip grid word bedoel die graad van sosiale gehoorsaamheid van persone van 'n groep aan die gemeenskap se simboliese sisteem, die sisteem van klassifikasies, definisies en evaluasies, waardeur die gemeenskap sy lede in staat stel om orde en betekenis aan hulle ervarings te skep. Met group word bedoel die mate van sosiale druk wat op 'n persoon of subgroep geplaas word om te konformeer met die breë gemeenskap se eise en om tussen grenslyne wat die groep afbaken, te bly. Volgens Malina (1986:203) reflekteer Matteus se gemeenskap 'n sterk groep, lae graad samestelling. Crosby (1988:111) definieer die sterk groep-lae graad van Matteus se gemeenskap soos volg:
}

Strong group characteristics involve clear group identity with pressure to conform, definite "insiders" and "outsiders" with clear division of their boundaries, along with normative symbols which define, express, and continue the group identity. Low grid indicates a low degree of fit or match between an individual's experiences and societal patterns of perception and evaluation. 
Honor and shame were key factors related to grid-group insofar as honor and shame constituted cultural norms within and among preindustrial households. Because wealth was not accumulated (systemic accumulation being a sign of capitalism), power dominated in such precapitalist, traditional societies as that of Matthew. With power defining society, rank and status determined relationships among members in that society.

Eer en skande is die sentrale morele waardes van die verhoudings wat georden is rondom rang en status. Malina (1981:25-50) beskryf eer as sosiaal aanvaarbare optrede en gedrag in die arena waar drie lyne van mag, rang vir mans en vrouens en godsdiens mekaar kruis. Die soek van geregtigheid in die hof, van 'n persoon met gelyke status, is 'n oneerbare optrede. Om hof toe te gaan is 'n oortreding van die eer-kode en sodoende word skande oor die huisgesin gebring (vgl Matt 5:24-25). In Matteus is die ekklesia die laaste vlak waar konflik tussen lede opgelos kan word (Matt 18:17). Matteus veronderstel 'n gemeenskap van broers en susters wie se lewenstyl die beeld van God se heerskappy weerspieël (Crosby 1988:180). Dit is oneervol om die konflik tussen broers binne die gemeente na buite te neem, na ongelowiges.

Sterk-groep kulture ${ }^{3}$ waarvan eer en skande deel is, sluit resiprositeit in. In die kulture bepaal resiprositeit 'n etos van geregtigheid. Matteus beklemtoon dikaiosune as 'n doel vir sy gemeenskap teenoor die sogenoemde onregverdiges (hypokrites) $^{4}$ in Judaïsme, asook die breë gemeenskap, veral hulle leiers (5:20). Engelbrecht $(1985: 155,156)$ toon aan dat teleios ${ }^{5}$ die teenoorgestelde is van huigelary (hupokrites) en perverse deelsgehoorsaamheid. Matteus verstaan

\footnotetext{
${ }^{3}$ Malina (1991:66-87) toon die andersheid tussen die eerste-eeuse Mediterreense en Westerse begrip "persoonlikheid" aan. Malina beskryf Matteus se gemeenskap soos volg:
}

John the Baptist and Jesus, with their call for conversion, asked for people to break with belief in external responsibility, to realize that praize or blame for behaviour was their own, to seek a reward from God rather than live with the expected rewards from men. Of the Synoptic gospels, it seems that Matthew and his concern with the house of Israel saw the world in terms of internal responsibility and external control. In this the community of Matthew seems most like Jesus' original Galilean audience. Thus, the qualities featured in Matthew's Sermon on the Mount (Mt 5-7), like that document's directives on litigation (Matt 18), admit of external control, but quite distinctively underscore internal responsibility.

${ }^{4}$ Elliott (1989:53-65) wys op die verband tussen afguns (evil eye), redistribusie, limited good en die zero-zum game in kleinboergemeenskappe.

${ }^{5}$ Teleios (Matt 5:48) is die beginsel waarvolgens die ses antiteses van die wet uitgebrei word (Engelbrecht 1985:155, 156). 
geregtigheid as Jesus se vervulling van die wet en die profete binne die konteks van die Hebreeuse geskrifte. Om God te ken, is om regverdig op te tree (Jer 22:15-16) en die Goddelike orde te handhaaf. Die verband tussen verbond, geregtigheid, land, huis en Israel kan soos volg voorgestel word:

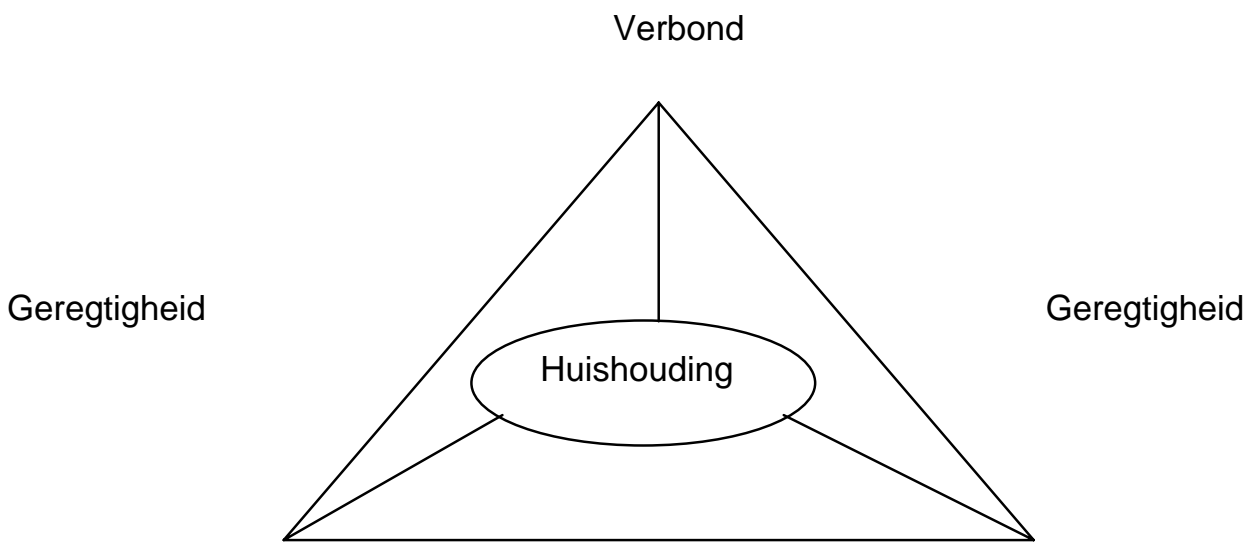

Huis van Israel

Geregtigheid

Land

Matteus se terme vir geregtigheid veronderstel bogenoemde verstaan. Crosby (1988:180) verstaan geregtigheid in Matteus soos volg:

\begin{abstract}
Within this understanding, as well as the understanding of justice as rightly-ordered relationships of persons with each other and their resources, I follow the position that 5:6 and 6:33 stress dikaiosune as the saving gift of God's presence and order in human's lives (i.e., "to know" God), while 5:10, 20, and 6:1 highlight human's response to others as their sign of fidelity to the saving gift of God's presence and order (i.e., "to do justice"). These five uses, besides the first words of Jesus about fulfilling all dikaiosune (3:15) and John's preaching dikaiosune (21:32), must be seen as the fulfillment of the Torah and the Old Testament covenant.
\end{abstract}

Om die verlossende krag van God se geregtigheid te ervaar bring seën, dit wil sê die vervulling van God se verlossingsplan. Lede van Matteus se gemeenskap is getuies van hierdie verlossingsdaad van God se geregtigheid deur hulle eie dade van geregtigheid (Matt 5:10, 20; 6:1). In Matteus 5:17 word verklaar dat Jesus die wet en profete kom vervul het. Jesus is dus die beeld van die Goddelike tora, wat God se ekonomie is, dit wil sê God se manier om geregtigheid te versprei. 
Geregtigheid is verlossing en openbaar die weg van verlossing. Die huishoudings wat die verlossing en ekonomiese elemente van geregtigheid vervul, vervul die tora. Hulle moet Jesus navolg in die vervulling van die wet en profete. Matteus toon dus van die begin af ' $n$ verband aan tussen vervulling en geregtigheid. Die wet en profete word vervul deur die werke van geregtigheid:

The experience of God's salvation or reign in heaven is contingent on the exercise of justice on earth, and the reordering of life on behalf of the poor is the sine qua non for entrance into heaven for those wanting to be perfect (19:21). With its increasing prosperity, Matthew's community was tempted to adapt to the surrounding culture. These words $(5: 20)$ and what follows $(5: 21-58)$ call it to express a justice that set it apart from its society's norms for justice.

(Crosby 1988:182)

Jesus is die model van dissipelskap (vgl Crosby 1988:183), net so is die huis van die skrifgeleerdes en Fariseërs simbool van leiers (kerk, ekonomie of politiek) van alle tye, wie se gedrag nie ooreenstem met hulle woorde nie (Matt 23:3-4).

\section{DIE BERGREDE, JUBILEE EN HUISORDE}

Crosby (1988:181-195) toon oortuigend aan dat die jubilee die gepaste agtergrond is van Jesus se gebed en die bergrede as geheel. Die jubilee beskryf ' $n$ herstelproses in verband met grondbesit en verhoudings. Maar die verstaan van die jubilee, alhoewel dit ten grondslag lê van die bergrede en gebed, word deur Jesus verruim om 'n totaal nuwe waardesisteem en gemeenskap (huishouding) in te sluit. Die herordening (herstrukturering) moet plaasvind, maar dit is slegs die begin van 'n nuwe gemeenskap. Vervolgens sal die verband tussen Matteus se bergrede en die jubilee aangetoon word.

\subsection{Geregtigheid en algemene resiprositeit}

Die stellings oor die wet in Matteus 5:17-19 het een praktiese doel: geregtigheid as voorwaarde vir lidmaatskap in God se heerskappy. Geregtigheid is die basis van die wet en ordening van die huis. Dit is gegrond in die antitese: Julle het gehoor dat daar gesê is ... maar Ek sê vir julle. Stellings 1, 2, en 4 is unieke Matteus-stellings, maar in stellings 3, 5 en 6 verander Matteus Lukas, veral om familiale verhoudings te beklemtoon. In die vyfde (Matt 5:38-42) stelling - die wet op vergelding - gee Matteus se Jesus visie vir herstrukturering van etiek en 
huisordening. 'n Gemeenskap wat beïnvloed is deur eer en skande, versterk die wet van vergelding (Eks 21:24; Lev 24:20; Deut 19:21). Resiprositeit vermy voortdurende antagonisme onder huishoudings en familie. Vergelding is gegrond op tradisionele patriargale modelle van resiprositeit en onderdanigheid. Jesus daag hierdie waardes uit met die stellings van geen weerstand. Jesus stel 'n nuwe soort onderdanigheid voor aan die ordening van die huishouding - doen goed, selfs aan die vyande en vervolgers (Crosby 1988:183).

In die tyd van die Matteus-evangelie was die verhoudings tussen die magtiges en magteloses, grondeienaars en huurders beheer deur negatiewe resiprositeit, gebalanseerde resiprositeit en algemene resiprositeit. Jesus het die tradisionele benadering tot die wet van resiprositeit omgekeer en eis algemene resiprositeit, dit wil sê om aan almal goed te doen. Doen goed aan almal, want almal is deel van God se huishouding. Die bergrede praat van goeie werke en vrugte dra, wat geen vergelding beteken nie, maar deel van lewensmiddele klere, tyd ensovoorts, deur middel van algemene resiprositeit. Matteus se Jesus nooi die dissipels uit om 'n nuwe huisorde te skep van algemene resiprositeit (Crosby 1988:184). In die bergrede kondig Jesus nie 'n nuwe sosiale program vir die gemeenskap aan nie, maar die einde van die gemeenskap. Die einde van die wêreld soos dit legalisties, polities en ekonomies georden is. Jesus kondig 'n nuwe era aan waar lewensmiddele vrylik deur almal gedeel word.

Jesus rig met die sesde stelling (Matt 5:43-47) 'n verdere uitdaging aan die gemeenskapsnorme oor geregtigheid en resiprositeit waarmee die bestaande orde weer omgekeer word. Die liefdesgebod word verder uitgebrei, naamlik: Jy moet jou vyand liefhê. Crosby (1988:185) verklaar die stelling soos volg:

At the time of Jesus, love of neighbour meant love of "insiders", those of one's extended family or religion - in this case, the Jews. "Outsiders" were real or possible enemies. However, given the tensions inside as well as outside his house churches, Matthew's Jesus realized that enemies could be everywhere, including one's own household (10:36) and city.

When Jesus said to love enemies, he was expanding the traditional practice beyond the doors of the oikia to the oikoumene, saying: love those within and beyond your household. Let your love be nonexclusive. However, this love was not merely to be a matter of affection; it was to be a manifestation of justice (5:20). This justice had to manifest a reordering of the whole household. Moreover, from the household, it had to extend to the village or city around. 
Liefde vir die vyand het beteken dat die persoon 'n kind is van die hemelse Vader. Israeliete het geglo dat 'n mens deur goeie werke 'n kind van God word. Die goeie werke, die wil van God, is die konstituering van die nuwe huishouding (huis-orde) van regverdiges (Matt 5:45; 10:41; 13:43, 49; 25:37, 46). Die huishouding is meer omvattend as die familie. Die universaliteit van die huishouding moet na die hele skepping uitgebrei word (Matt 5:46-47). Liefde vir die vyand word verder ook as 'n universele ekonomiese beginsel verstaan, dit wil sê, 'n inklusiewe ekonomiese uitruil gebaseer op algemene resiprositeit (Oakman 1986:215, 216; Crosby 1988:186).

\subsection{Die weg na heelheid (teleios)}

In Matteus 5:48 kry ons die doel van die antitetiese stellings: Wees julle dan volmaak, soos julle hemelse Vader volmaak is. God se volmaaktheid kom na vore wanneer ons van ons vyande ons vriende maak. Matteus se huiskerk is die draers van God se integriteit (Matt 19:21), wanneer hulle die grense afbreek en die huis van gelowiges inklusief verruim. Die armes en die gemarginaliseerdes word ingesluit en verder word die liefde vir die vyand beklemtoon. Crosby (1988:186) beskryf baie duidelik die verband tussen geregtigheid en heelheid as 'n eis vir inklusiwiteit wat die skrifgeleerdes en Fariseërs se geregtigheid oortref:

Justice is identified with "perfection"; its salvific expression becomes the goal of an ethical life of love. Just as the Essenes considered their community the "house of perfection and truth in Israel to establish the covenant according to everlasting precepts" (1 QS xi, 11, 17), so Matthew's language in 5:48 suggests his households must live up to the demands of the new covenant through a similar justice.

Crosby (1988) oorbeklemtoon die horisontale aard van geregtigheid (herordening van lewensmiddele en verhoudings) ten koste van die vertikale verhouding (die verhouding met God). Geregtigheid impliseer 'n verbondsverhouding tussen God en mens wat in die regte verhouding tot mekaar staan (Achtemeier 1982:91-99; Engelbrecht 1985:162).

Engelbrecht (1985:157-173) toon aan dat geregtigheid nie 'n eenheidsbeeld vertoon nie; daarom is die verwysingspektrum genuanseerd. In hierdie genuanseerdheid is egter altyd 'n vaste kern teenwoordig waarin lojaliteit en gehoorsaamheid die sleutel rol speel. Die polarisasie van die betekenismoontlikhede van geregtigheid wissel tussen geregtigheid as 'n eis aan die mens (die horisontale dimensie; vgl Crosby 1988 - GV), teenoor geregtigheid as gawe 
van God (die vertikale dimensie; vgl Engelbrecht 1985). Geregtigheid figureer baie dikwels in 'n karakterkonteks (Engelbrecht 1985:158-161), veral in die polarisering van karakters of groepe teenoor mekaar. Geregtigheid moet binne die totale konteks van Matteus se teologie verstaan word (met Deuteronomistiese teologie as agtergrond-GV). Matteus gebruik geregtigheid baie nou saam met die verbondsteologie, wat sentraal is in die Matteus-evangelie. Engelbrecht $(1985: 162,163)$ toon 'n baie sterk verband aan tussen geregtigheid en genade of medelye in Matteus. Die konteks bepaal of eleos na genade of menslikheid/ medelye verwys. Dit is duidelik dat geregtigheid genuanseerde gebruiksmoontlikhede het. Dit verwys enersyds, binne die verbondsmotief na die vertikale verhouding tussen God en mens, dit wil sê die mens se lojaliteit en gehoorsaamheid aan God en die verbond. Andersyds, verwys geregtigheid na die horisontale verhouding en optrede van mense wedersyds. Geregtigheid beteken dan menslikheid of medelye. Crosby (1988) verteenwoordig dus 'n eensydige beklemtoning van die betekenismoontlikheid van geregtigheid. Dit kan die derde betekenismoontlikheid genoem word. Engelbrecht (1985:164) wys op die vervlegtheid van die Deuteronomistiese en wysheidsmotiewe in die gebruik van geregtigheid. Die Deuteronomistiese motief beklemtoon die verbondsteologie en dus geregtigheid as lojaliteit en gehoorsaamheid aan Jesus. Matteus se oproep tot geregtigheid (pad van geregtigheid - EE) is dus Christologies bepaald. Die wysheid se oproep tot geregtigheid fokus op die kennis van die beginsels wat die Here neergelê het om die wêreld en gemeenskap te orden (vgl Schmid 1968:97; Engelbrecht 1985:165). Crosby (1988) se verstaan van geregtigheid as die regte ordening van lewensmiddele en relasies, sluit sterk aan by die wysheidsmotief wat Engelbrecht (1985:164) aangetoon het. Daarteenoor kan Matteus se geregtigheidsbegrip soos volg saamgevat word:

Dit is dus duidelik dat die humanistiese geregtigheidsbegrip wat bloot horisontaal funksioneer deur aan elkeen te gee wat hom toekom, ingrypend verskil van Matteus se geregtigheidsbegrip. Matteus se geregtigheidsbegrip polariseer nie die onregverdiges en die regloses nie, maar die wat aan Jesus lojaal is en die wat Hom verwerp.

(Engelbrecht 1985:182)

Verder konkludeer Engelbrecht (1985:183) dat:

Juis omdat die verbond in sy Christologie so sterk figureer, staan Jesus sentraal as Matteus oproep tot lojaliteit en gehoorsaamheid. Die 
tendens in die ekumeniese teologie om sosiale geregtigheid as die hart van die Bybelse boodskap te verstaan, kan hom nie op Matteus se geregtigheidsbegrip beroep nie, omdat menslikheid by hom in die raam van die verbondsdenke ingesluit is.

Die sosiale dimensie van geregtigheid moet nie deur hierdie kritiek uit die oog verloor word nie. Die gevaar kan bestaan dat daar 'n karikatuur van die ekumene se "sosiale geregtigheid" gemaak word. Geregtigheid het vir Matteus (en die Ou Testament, asook vir Paulus) sosiale implikasies.

\subsection{Jubilee, herordening en geregtigheid}

Matteus 6:1-18 bestaan volgens Davies \& Allison (1988:63) uit verskeie triades. ${ }^{6}$ Dit is een van die uitstaande kenmerke van Matteus se redaksionele werk. Die perikoop is swaar gelaai met jubilee-terminologie. Jesus waarsku teen die doen van goeie werke om deur mense gesien te word. Die Vader in die hemel verwag van die lede van die huishouding 'n ander soort geregtigheid wat uitgedruk word in aalmoese (Matt 6:2-4), gebed (veral die kwytskelding van skuld [Matt 6:4-15]) en vas (Matt 6:16-18). Dit is spesifieke maniere hoe die wet en profete vervul word en geregtigheid uitgeleef word (vgl Engelbrecht 1985:159). Knierim (1995:242-243) lê 'n duidelike verband tussen voedsel, land en geregtigheid.

\subsubsection{Aalmoese}

In Matteus se huishouding was 'n groot gaping tussen die magtiges en magteloses, ryk en arm, diegene met status en die gemarginaliseerdes. Die Hebreeuse geskrifte roep die boonste sosiale klasse tot verantwoordelikheid om die onderste klasse se behoeftes te vervul in resiprositeit van reg en geregtigheid. Die lewensbronne moet met reg en geregtigheid gebruik word ter wille van die armes, wat gehelp het in die akkumulasie van die rykdom (Crosby 1988:186). Die manier waarop dikaiosune tot uiting kom, is deur eleemosune (Matt 6:1). Eleemosune het implikasies vir die ekonomiese etiek wat gegrond is op die gee van aalmoese. Die gee van aalmoese in die Matteus-evangelie gaan verder as wat die wet vereis (Matt 19:16-19):

${ }^{6}$ Davies \& Allison (1988:63) gee die volgende uiteensetting van die triade in Matteus 6:1-18:

- Algemene beginsel (6:1);

- Spesifieke opdrag (6:2-18);

- Aalmoese (6:2-4);

- Gebed (6:5-15) - Hoe om te bid: nie soos huigelaars in die sinagoge nie (6:5-6);

- Hoe om te bid (6:7-15); * Nie soos heidene (6:7-8); 
In contrast to a society whose approach to the poor often was based on exploitative forms of redistribution, Matthew's Jesus demanded of his disciples a general reordering of possessions and status on behalf of those without possessions or status, namely the poor (19:21). The concrete expression of this mercy or almsgiving was to go further in meeting the requests of those who ask or in responding to those who take (5:40-42). Again almsgiving was not so much a matter of charity as an essential demand of justice.

(Crosby 1988:187)

Barclay (1965:186-188) wys daarop dat die gee van aalmoese vir die Jood net so belangrik was soos geregtigheid. Dieselfde woord word vir beide begrippe gebruik.

\subsubsection{Gebed}

Gebed is die tweede wyse waarop geregtigheid uitgedruk word, sodat God se wil ook op aarde geskied, net soos in die hemel. Die eerste petisies van die gebed vorm 'n triade, net soos in Matteus 19:29 waar Matteus die naam en koninkryk identifiseer met die wil van God. God se Naam moet dus geheilig word, God se heerskappy kom en God se wil geskied op die aarde, net soos in die hemel. Die lede van Matteus se huishouding moet deur die gebed hulle goeie werke in die wêreld doen. Die gebed pleit dus ook vir 'n herordening van verhoudings en lewensbronne op aarde. Crosby (1988:188) stel dit soos volg:

We have already seen that "heaven and earth" refer to God's presence. By working for conditions on earth that give praise to God's name, the reign of God's will is continued in the work of Jesus and the church (11:2-6). The order in the heavenly household is imaged in the earthly order. These petitions call for a reordering of relationships and resources to manifest on earth the fulfillment of God's plan. These petitions stand as subversive to whatever keeps the world in darkness rather than light, in chaos rather than order.

Gee ons ons daaglikse brood (Matt 6:11), spreek die mees basiese ekonomiese behoefte van die mens op aarde aan. Mense gee hulleself volledig oor aan God se voorsienigheid, in absolute vertroue op God. Barclay (1965:199) wys daarop dat die tweede deel van die gebed (Matt 6:11-13) die verlede, hede en toekoms van die menslike bestaan onder God se heerskappy plaas. Die afhanklikheid van 
God het ekonomiese en "eucharistiese" ondertone. Ons is almal hulpbehoewend. God gee ons wat ons nodig het en God gee net genoeg. Die huiskerke moes hulle huise so orden (ekonomiese toestande skep), sodat hulle ook in die behoefte van ander kon voorsien. Hulle moes genoeg vir hulleself soek, maar ook ander hulle skuld vergewe (Crosby 1988:188; Knierim 1995:240-243).

\subsubsection{Implikasies vir skuldvergifnis}

Die petisie van skuldvergifnis (Matt 6:12) beklemtoon die ekonomiese herordening in die huishoudings en lede van verskillende huishoudings. Skuld het bygedra tot die spanning tussen die besittersklas aan die een kant en aan die ander kant, die huurders en arbeiders in Jesus en Matteus se tyd. Skuld is 'n belangrike meganisme waarmee die rykes ryker geword het en die armes armer. Met hulle mag het hulle winskopies geskep. Hulle het die terme van die opbrengs van surplus produkte gedikteer en van hulle werkers geëis tot hulle eie voordeel. Die model van die gevorderde agrariese samelewing, spesifiek die sosiale stratifikasie, het die groot onderskeid tussen die elite en die ondersteuners, kleinboere en gemarginaliseerdes aangetoon. Die sosiaal-wetenskaplike kommentaar van Malina \& Rohrbaugh $(1992: 58,59)$ maak slegs in die verbygaan 'n opmerking in verband met skuld. Crosby (1988:188-190) beklemtoon pertinent die belangrikheid van skuld en kwytskelding van skuld (ekonomies en legalisties) in die gebed van Jesus.

Matteus gebruik die term ofeleima vir sonde of skuld. Die term omsluit drie vlakke van skuld (LaVerdiere 1983:132): skuld van geregtigheid, skuld van dankbaarheid en skuld vir oortredinge.

- $\quad$ Skuld van geregtigheid dui op 'n soort verpligte gemeentelike geregtigheid waarin werkgewers verplig is om arbeiders hulle loon te betaal.

- $\quad$ Skuld van dankbaarheid verwys na die terugbetaling van skuld op grond van ooreenkomste met hulle wat geld skuld. Vergelyk die groot skuldenaar waarvan baie skuld vergewe is (Matt 18:32-33).

- $\quad$ Skuld vir oortreding dui op skuld wat 'n verhouding vernietig of wat versoening eis. Alles dui op 'n afhanklike verhouding tussen die betrokke partye. Matteus maak baie van geregtigheid as 'n manier van ekonomiese skuldvergifnis (Matt 18:21-35). 
Die kwytskelding van ekonomiese skuld figureer sentraal in die jubileejaar, wat die herstrukturering van grondbesit bepaal volgens die oorspronklike situasie elke vyftig jaar. Jesus het gekom en die jubilee afgekondig (Matt 11:2-6) en Hy het gesê dat die kenmerke van ware dissipelskap is om jou besittings te herorden tot voordeel van die besitloses (Matt 19:21). Die petisie oor skuldvergifnis in Jesus se gebed vra 'n verbintenis van individue en die groep tot ekonomiese herordening. Dit sluit die herordening van relasionele skuld, asook materiële en ekonomiese skuld in (Crosby 1988:189). Die Septuaginta gebruik die woord afesis (werkwoord afienai) vir die jubilee wat vra vir vergifnis van skuld (Lev 25:23ev). Afesis beteken beide kwytskelding van skuld en vergifnis van sonde. Jesus roep dus volgens Matteus die mense op om die jubilee in werking te stel (kyk Ringe 1985:65-80).

\subsubsection{Implikasies vir die jubilee}

Die metafore en beelde grondliggend aan die woorde en dade van Jesus toon sterk ooreenkomste met die Sabbat-jubilee wetgewing (Lev 25 en Deutero-Jes) in verband met die bekering van die gemeenskap. Crosby (1988:190) beskryf die implikasies van die jubilee soos volg:

Leviticus 25 outlined conditions that would convert society to its more egalitarian origins. The original covenant, intended to preserve the honor of Yahweh and Israel, would be recalled in an effort to proclaim liberty to all inhabitants, to restore property to rightful heirs, and to cease agricultural activity for one year (Lev 25:10-12). The Sabbathjubilee insisted on insuring that the needs of the poor be met in order to offset Israel's anticipated break of the covenant and the dishonor Israelites would show each other and Yahweh by their exploitation of the poor who were always in need.

Volgens Hollenbach $(1986: 153,154)$ moet die armes se behoefte bevredig word binne drie tydvakke - hulle onmiddellike nood vir voedsel en klere; hulle korttermyn behoefte vir familiale herstel en hulle langtermyn behoefte vir totale sosiale rekonstruksie. Die basiese of onmiddellike behoeftes word voortdurend deur familiale sorg bevredig. Die korttermyn behoeftes kan na aanleiding van die situasies deur verlossing bevredig word en die langtermyn behoeftes kan opgelos word elke vyftig jaar deur strukturele vrylating. Crosby (1988:190) stel die plek en funksie van die huishouding soos volg: "Kinship ties expressed in care and redemption were to address individual needs within households. If 
households (oikos/oikia) would be reformed, it would lead to structural release which would meet the needs of the wider community (polis) and the entire society (basileia)."

Bogenoemde beskrywing van die funksionering van die jubilee deur Hollenbach (1986:154; kyk Crosby 1988:190) kan soos volg voorgestel word:

Conversion of households (oikos/oikia) through

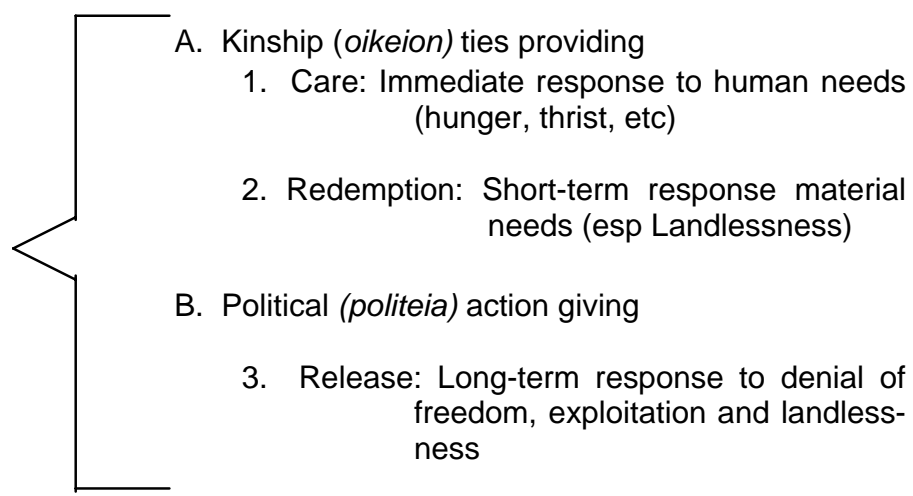

Crosby (1988:191) toon oortuigend aan dat die Sabbat-jubilee temas van sorg, verlossing en vrylating grondliggend is aan die Matteus-evangelie en veral Jesus se woorde en werke.

- $\quad$ Sorg of medelye. Die Sabbat-jubilee eienskap van sorg of medelye in reaksie op die mens se fisiese nood is kenmerkend van Jesus se bediening in Matteus (Matt 9:36; 14:4; 15:32; 18:27; 29:34). Daarom moet die lewe van Jesus se dissipels ook gekenmerk word deur die bevrediging van die nood van die hulpbehoewendes (Matt 19:21; 25:31-46).

- $\quad$ Verlossing. Die vorm van grondbesit in die tyd van Jesus het verlossing net 'n droom laat bly. Die kwytskelding van skuld van Jesus se gebed (Matt 6:12), pleit vir geestelike, maar ook besliste ekonomiese verlossing of kwytskelding.

- $\quad$ Vrylating of losmaking van gebruike en houdings wat mense se eer en waardigheid aantas, is duidelik in Jesus se gebruik van exousia, wat mense vrymaak van verwerping, lyding en sonde. Die meer politieke soort van vrylating van die armes is ook in Jesus en die dissipels se werk sigbaar (Matt 11:2-6). Die werk verwys na Jesaja se verwysing na die Messias en die Sabbat-jubilee vervulling (Jes 61). Matteus verwys ook na 
vrylating in die herordening van die eerste en laaste in die nuwe huishoudings van geloof (Matt 19:29-30); die verwerping van die stede wat weier om te herorden (Matt 11:20-24; 23:37-39); asook die aanvaarding van enige groep (Matt 8:11-12; 23:31) of nasie (Matt 25:31-46) wat reageer op God se wil om die armes se nood te verlig (Crosby 1988:191).

Crosby (1988:191) kom tot die volgende gevolgtrekking:

Thus, because care, redemption and release were at the heart of the Sabbath-jubilee and because these same characteristics constitute the heart of Matthew's interpretation of Jesus, the first gospel clearly indicates notions of social conversion which reflect the Sabbath-jubilee, and those notions reinforce the phrase about forgiveness of debts in the Lord's prayer.

Ringe $(1985: 84,85)$ stel dat die Onse Vader 'n jubilee-gebed is, omdat elke petisie indirek verwys na die jubilee-beelde. Crosby (1988:191) bevestig die opmerking dat die jubilee grondliggend is aan die bergrede en die gebed.

\subsubsection{Vas}

Die frase, En lei ons nie in die versoeking nie, maar verlos ons van die bose (Matt 6:13), behoort ook nie losgemaak te word van die ekonomiese of huisordekonteks binne Matteus nie. In die Matteus-evangelie is vas die derde manifestasie van geregtigheid (Matt 6:16-18). Die frase staan waarskynlik in verband met Jesus se versoeking in die woestyn. Nadat Jesus aangekondig het dat Jesus gekom het om geregtigheid te vervul, is Jesus die woestyn in om versoek te word (personifikasie van ongeregtigheid) en het Jesus begin vas. Jesus het met medelye teenoor diegene opgetree wie se ekonomiese situasie vereis het dat hulle vas, omdat hulle geëksploiteer is. Jesus het die bronne gebruik om hulle nood te verlig (Matt 15:32). Jesus se bediening aan die armes verteenwoordig 'n tipe van vas, of 'n herordening van bronne ter wille van die armes (Matt 9:14-15). Die herordening (kyk Matt 26:11-13) moet deur die dissipels nageboots word, omdat Jesus met hulle is, nie fisies nie, maar in exousia (kyk Matt 28:16-20).

Matteus steun baie sterk op Deutero-Jesaja, baie meer as enige ander evangelis. Vir Matteus was Jesus die vervulling van die geregtigheid wat Jesaja verkondig het. Crosby (1988:191) stel dit soos volg: 
Thus, it follows that the first gospel's notion of fasting would parallel that economic reordering described by Isaiah in chapter 58 as the essence of fasting. Isaiah railed against those who exercised the ritual of fasting without reordering those economic conditions that exploited people and perpetuated economic dependency. In fact, people were often oppressed and treated unjustly by precisely those practicing the ritual of fasting (Is. 58:1-5). Isaiah's Yahweh called for a new kind of household ordering geared to a deeper form of justice - that which bring good news to the poor.

In die konteks moedig Matteus sy huiskerke aan om geregtigheid uit te leef deur die naaktes te klee en die hulpbehoewendes se nood te bevredig (Matt 25:3145). Dit is deel van Matteus se vas, wat die gemeenskap se ongeregtigheid aan bande sal lê en sal verhinder om die lede van die huiskerke te oorweldig. In 'n wêreld van ongeregtigheid sal vas help om die situasie te herstel (Crosby 1988:192).

\section{KEUSE TUSSEN GOD EN MAMMON}

Die geregtigheid, dit wil sê die herordening van die huishouding en welvaart ter wille van die armes, moet gehandhaaf word deur goeie werke. Dit vereis 'n purity-of-the-heart perspektief teenoor welvaart (mamonas [Matt 6:19-32]). In Matteus beteken Mammon iets goddelooslik wat verstrengel (Matt 6:19, 21, 24). Om die Koninkryk of heerskappy van God in te gaan beteken 'n geregtigheid wat dié van die skrifgeleerdes en Fariseërs oortref. Verder moet aalmoese, gebed en vas (Matt 6:1-18) deel wees van die geregtigheid, maar die grootste struikelblok is die hardheid van die hart, wat deur Mammon in verskillende vorme veroorsaak is (Crosby 1988:192). Liefde vir God en die naaste is die fondament van die wet en profete (Matt 22:37-40; verder ook Matt 5:43-46; 19:19). Liefde is die kern van geregtigheid wat die fondament van die wet en profete is. Liefde, asook geregtigheid moet gerealiseer word in goeie werke. Goeie werke is die vervulling van die wil van die Vader. Wetteloosheid (anomia) is 'n gebrek aan liefde. Die hart is die sentrum van die lewe en die simbool van liefde, daarom sal dikaiosune of anomia daaruit voortkom met al die implikasies (Crosby 1988:192).

\section{GEREGTIGHEID EN REGGEORDENDE VERHOUDINGS}

In Matteus 6:33 stel Jesus 'n uitdaging aan die lede van Matteus se welvarende huiskerke: Soek eers die Koninkryk van God en sy geregtigheid (die laaste deel is deur Matteus self bygevoeg). Om die koninkryk te soek beteken om tot God te 
bekeer. Bekering beteken bekering vanaf iets of ' $n$ toestand. God se verlossingswerk in die dissipels se lewe vereis 'n ekonomiese herordening om sodoende die goeie nuus vir die armes te bring. Die herordening moet plaasvind om sodoende die Koninkryk van God te ervaar (Matt 19:21). Soek eers die heerskappy van God en sy orde in die lewe (dikaiosune), dan sal God se liefdevolle sorg as Vader ervaar word.

Soek eers die koninkryk van God is die fondament van die volgende twee perikope, naamlik om met medelye en opregtheid teenoor ander op te tree (Matt 7:1-6) en die afhanklikheid van God se voorsienigheid en sorg (Matt 7:7-12). Die eerste perikoop waarsku teen oordeel in huishoudings. Om te oordeel dui 'n tipe van huigelary (hupokrites) aan. Matteus kontrasteer hupokrites met geregtigheid en goeie werke. Huigelary is die gebrek aan koherensie tussen woorde en werke, die beeld van een ding teenoor die realiteit van 'n ander. Matteus se etiek kan slegs verstaan word met die klem op geregtigheid ${ }^{7}$ in sy huishouding teenoor huigelary (kyk Crosby 1988:193). Die tweede perikoop sluit in die triade van vra en ontvang, soek en vind, klop en oopmaak (Matt 7:7-12). Matteus toon hiermee die benadering aan wat sy huiskerke moet volg in gebed. Matteus kom tot die konklusie: As julle wat sleg is weet om goed te doen vir die kinders, hoeveel te meer julle Vader in die hemel. Matteus se welvarende huiskerke, wat voor die versoeking staan om selfsugtig op hulle eie lewensmiddele te vertrou, moet luister na die uitdaging. Matteus sluit die gedeelte af met Matteus 7:12, naamlik: Alles wat julle wil hê die mense aan julle moet doen, moet julle aan hulle doen. Dit is tog waarop dit neerkom in die wet en die profete. Geregtigheid is die vervulling van die wet en die profete, maar meer nog, geregtigheid is die gelyke behandeling van almal in die gemeenskap. Dit beteken dus liefde vir jou naaste, soos vir jouself (Matt 20:19; 22:36-40) (kyk Crosby 1988:193).

Die bergrede word afgesluit met die verwysing na twee soorte huise: die een wat op sand (woorde sonder werke) gebou is en die een wat op rots gebou is (Matt 7:24-27). Die lede van die huishoudings moet leef onder die gesag (exousia) wat hulle by hulle doop ontvang het (Matt 28:16-20). Dit is dieselfde gesag wat die skare verbaas gelaat het oor Jesus se onderrig (Matt 7:22-29). Met dié gesag moet hulle die onderrig van Jesus gaan uitleef; hulle moet alles onderhou wat Jesus hulle geleer het. Die bergrede word dus afgesluit met huis, net soos dit met huis begin is (Crosby 1988:195).

\footnotetext{
${ }^{7}$ Senior (1979), maar veral Reumann (1985) lê 'n baie sterk verband tussen die geregtigheid en die ekonomie van God.
} 


\section{DIE VERBAND TUSSEN GOD AS HUISEIENAAR, HUISORDE (EKONOMIE) EN JUBILEE}

Die verband tussen God as huiseienaar en die wêreld kan soos volg aangetoon word: In Matteus verwys Jesus na God se heerskappy as dié van 'n huiseienaar. Die metafoor van God as Goddelike huiseienaar (Meeks 1984:3; vgl Crosby 1988:171) kan beskou word as primêre metafoor regdeur die Skrif. Crosby (1988:171) verwys terug na Psalm 24 en wys op die Jode se verstaan van God as Huiseienaar van die hele wêreld:

Psalm 24 begins, "The earth is the Lord's and the fullness thereof, the world and those who dwell therein; for he has founded it upon the seas, and established it upon the rivers" (Ps 24:1-2). As Psalm 24 indicates, the Hebrews envisioned God's role in creating the world to be like that of a builder of a house (see Ps. 127:1) in possession of the entire world (Ex 19:5; Ps 89:12; 95:5), which contained all households. In this sense, the Hebrews considered themselves God's special household within the household of the universe - all ordered religiously and economically by the divine Householder.

Die Griekse woord vir die hele bewoonde wêreld is oikoumene, wat met oikos/oikia verbind kan word. Matteus is die enigste evangelie wat die hele bewoonde wêreld gebruik in die konteks waar die evangelie verkondig moet word (Matt 24:14) deur die lede van Jesus se huishouding (Matt 10:25), sy kerk (Matt 16:18). In die antieke tyd het die ekonomie verwys na God wat die primêre Huiseienaar is, die Besitter van die wêreld (Crosby 1988:172). Die mense is slegs die huisbestuurders (oikonomoi/ekonomoi). Met die skepping het God orde in die chaos gebring. Die ordelike verhouding tussen God, mens en die natuur of lewensbronne van die aarde word deur geregtigheid uitgedruk. Deur die herordening of geregtigheid moet die wêreld (oikoumene) na sy oorspronklike doel terugkeer. Die mens is man en vrou geskape om die Godgeskape orde te handhaaf en die aarde te bewoon, te bewaar en te bewerk. Douglas Meeks (1984:4; kyk Crosby 1988:172) stel die saak soos volg:

... in God's economy the only thing that ultimately separates the human being from the rest of the animals is that the human being is called into being in order to keep God's household. This is what constitutes being a human being. Being human is an economic commission: to join God the Economist in distributing righteousness so that the world may live. 
God se ekonomie kan nie losgemaak word van die menslike ordening van die wêreld op grond van geregtigheid nie. Dike of geregtigheid beteken die basiese ordening van die wêreld. Die regverdige mens is die een wat die universele orde handhaaf. Man en vrou moet as beeld van God op regverdige wyse die skeppingsorde van God handhaaf. Die werklikheid van die mens se bestuurderskap is dat hulle afvallig geword het. Die mens, die huisbestuurders van God was ontrou en onregverdig in die deel van die lewensbronne en die verhoudings. Sommige het God se aarde vir hulleself toegeëien en sodoende die armes onderdruk en hulle geregtigheid ontneem. Die jubileewetgewing is ingestel om die menslike gierigheid en onregverdigheid te herstel. Die jubilee het ten doel gehad om te voorkom dat permanente verarming geïnstitusionaliseer word.

Die konteks of agtergrond van die jubilee en geregtigheid is dus God se skeppingsorde. Volgens Crosby (1988:173) is die jubileewetgewing in drie periodes saamgestel, maar hy bly in gebreke om die periodes te verduidelik: die eerste is Eksodus 21-23, Deuteronomium 12-26 is die tweede fase en Levitikus 1-27 die derde fase, wat in die konteks van die ballingskap ontstaan het. Die jubilee beskryf 'n soort ekonomiese herstrukturering, sodat die wêreld (oikoumene) na sy oorspronklike doel kan terugkeer. Crosby (1988:173) beskryf die herstel soos volg:

The redemption of the land would return the whole oikoumene to the original plan for the oikos/oikia (a central theme of the legislation [Lev. 25:29-34]). The redemption of the land would also create an ecological (oikos/oikia) order (Lev 25:11). Furthermore, the jubilee invited the people - images of God the Creator/Householder - to share the world's resources in a manner that reflected God's original economic or ordering of the house (Gen 1:26-28). Thus every fifty years "a comprehensive scenario for economic reform [which] encompassed slave release, interest free loans, debt release and the restoration of land to the original owners" was to take place throughout the house of Israel.

\section{SAMEVATTING}

In hierdie artikel is die meervoudige betekenismoontlikhede van geregtigheid aangetoon. Matteus verstaan geregtigheid as Jesus se vervulling van die wet en profete. Resiprositeit is die etos van geregtigheid, naamlik die regte ordening van verhoudings en lewensmiddele. Die gevolgtrekking kan dus gemaak word dat geregtigheid die saambindende krag is tussen God se verbond, land (ekonomie), 
Israel en die huisgesin. Die driehoekmodel is ' $n$ voorstelling van die interafhanklikheid en interrelasie tussen die elemente.

In die artikel is ook aangetoon dat die jubilee ten grondslag lê van die bergrede en die gebed van Jesus. Alhoewel die jubilee verstaan word as 'n herstelproses of herordening van 'n wanbalans (ekonomies/grondbesit en relasioneel), verkondig Jesus 'n totaal nuwe begin. 'n Nuwe gemeenskap wat gegrond is op algemene resiprositeit (ekonomiese herverdeling) en 'n universele huishouding gegrond op geregtigheid as die doen van God se wil. Die begronding van inklusiwiteit van die nuwe huishouding is die wese van God self, naamlik God se volmaaktheid.

Geregtigheid behoort nie net horisontaal verstaan te word nie, maar ook vertikaal. Geregtigheid is gegrond in God se verbond met die mens. God is regverdig, daarom moet die mens ook regverdig wees. Die mens kan geregtigheid op drie maniere uitleef, naamlik deur aalmoese, gebed en vas. Die jubilee is grondliggend aan die drie vorme van geregtigheid wat die herstel van ekonomiese en relasionele wanbalans ten doel het. Die herstel volgens die jubilee omsluit die mens in totaliteit. Die wanbalans van die mens se persoonlike behoeftes moet herstel word, die familiale bande wat verbrokkel het as gevolg van eksploitasie, moet herstel word. Laasgenoemde beteken dat die grondbesit reggestel en die samelewingsorde herstel word (eksploitasie teenoor algemene resiprositeit). Die jubilee pleit dus vir 'n algehele herstel (lewensmiddele en verhoudings) op horisontale vlak. Die vertikale verhouding met God staan voorop. Die regte verhouding teenoor God lei tot die regte verhouding teenoor die materiële sake (teenoor Mammon) en teenoor mekaar (relasioneel).

Dit is geen toeval dat Jesus se onderrig oor die nuwe gemeenskap en die jubilee in Galilea, Kapernaum en omringende gebiede plaasvind nie. Die plattelandse streke het die wanbalans op ekonomiese en relasionele vlakke die swaarste ervaar. Die relasie tussen geregtigheid, huisorde en jubilee behoort só ruim verstaan te word dat dit God se heerskappy oor die wêreld insluit. God is die primêre huiseienaar en die God van orde. God se skeppingsorde is die konteks of agtergrond van die jubilee en geregtigheid. Jubilee en geregtigheid dui dus albei op die regte ordening van verhoudings en lewensmiddele in die verruimde verstaan van albei konsepte (dit wil sê die multi-dimensionele aard daarvan). Die gevolgtrekking is dus dat die ordelike verhouding tussen God, mens en natuur (land of ekonomie) deur geregtigheid uitgedruk word. Deur ordening (geregtigheid) en herordening (jubilee) moet die wêreld na die oorspronklike doel terugkeer. 


\section{Literatuurverwysings}

Achtemeier, P J 1982. s v Righteousness in the New Testament. IDB.

Barclay, W 1965. Gospel of Matthew, Vol 1. Edinburgh: Saint Andrews Press.

Crosby, M H 1988. The house of disciples: Church, economics and justice in Matthew. New York: Orbis Books.

Davies, W D \& Allison D C 1988. The Gospel according to Saint Matthew's: A critical and exegetical commentary, I-VII . Edinburgh: T \& T Clark.

Donaldson, T L 1985. Jesus on the mountain: A study in Matthean theology. Sheffield: JSOT Press. (JSOT Suppl Series.)

Douglas, M 1966. Purity and danger: An analysis of the concepts of pollution and taboo. London: Routledge \& Kegan Paul.

Elliott, J H 1988. The fear of the leer: The evil eye from the Bible to Li'l Abner. Forum 4(4), 42-71.

Engelbrecht, E 1985. Sending en geregtigheid in die Matteus-evangelie. DD proefskrif, Universiteit van Pretoria.

Hollenbach, P W 1986. From parable to Gospel: Response using the social sciences. Forum 2, 67- 75.

Knierim, R P 1995. The task of Old Testament theology: Substance, method and cases. Eerdmans: Grand Rapids.

La Verdiere, E 1983. When we pray ... Meditations on the Lord's prayer. Notre Dame: Ave Maria.

Malina, B J 1981. The New Testament world: Insights from cultural anthropology. Atlanta: John Knox.

Malina, B J 1989. Dealing with Biblical (Mediterranean) characters: A guide for US consumers. BTB 19, 127-141.

Malina, B J 1992. Is there a circum-Mediterranean person? Looking for stereotypes. BTB 22, 66-87.

Malina, B J [1989] 1996. Christ and time: Swiss or Mediterranean?, in The social world of Jesus and the Gospels, 179-214. London: Routledge.

Meeks, D 1984. God as economist and the problem of property. Institute of ecumenical and cultural research. (Occasional papers, no 21.)

Oakman, D 1986. Jesus and the economic questions of his day. Lewiston: Edwin Mellon. (SBEC 8.)

Reumann, J 1985. The "righteousness of God" and the "economy of God": Two great doctrinal themes historically compared. Aksum-Thyateira: A Festschrift für Archbishop Mothodias of Thyateira and Great Britain, 615-637.

Ringe, S H 1985. Jesus, liberation, and the Biblical jubilee: Images for ethics and Christology. Philadelphia: Fortress.

Senior, D 1979. The Gospel of Matthew and the ministry of social justice. Spirituality Today 31, 14-25.

Schmid, H H 1968. Gerechtigkeit als Weltordnung. Tübingen: JCB Mohr.

White, L J 1986. Grid and group in Matthew's community: The righteousness/honor code in the Sermon on the mount. Semeia 35, 61-90. 